\title{
DEVELOPMENT OF A REFRIGERATION SYSTEM FOR COOLING MILK AT RURAL REGIONS
}

\author{
Morsi, M E. M. ${ }^{1}$
}

\begin{abstract}
The present paper presents an experimental evaluation of a solar refrigerator, prototype, based on an intermittent thermodynamic cycle of adsorption, using milk as refrigerant and the mineral zeolite as adsorber. This system uses a mobile adsorber, which is regenerated out of the refrigeration cycle and no condenser is applied. Because the solar regeneration is made in the ambient air for the regeneration, a SK14 solar cooker is considered. The cold chamber, with a capacity of 4 liters, is aimed for cooling milk. The objective is to analyze the advantages and disadvantages of the eventual use of this refrigerator in rural regions of Egypt, where no electricity is available. On the bases of the results obtained, a new prototype of refrigerator for rural regions is designed, based on the same thermodynamic cycle, but including changes in design and operation. According to the experiments Zeolite pan size of $2 * 20 * 25$ $\mathrm{cm}$ proved to be the most optimum, it is the size recommended for use in milk cooler. According to the results of the mathematical modeling of drying of zeolite, the best describing the drying characteristic is Wang and Singh model. The regression equation $R$ (correlation coefficient) indicates the degree of association between the observed and predicted values coefficient of efficient $\left(C_{e}\right)$ was 0.999.
\end{abstract}

\section{INTRODUCTION}

7 he use of sorption processes to produce refrigeration has been extensively studied in the last twenty years as a technological alternative to vapor compression systems. Several theoretical and experimental studies demonstrated the sorption refrigeration systems, especially that using solid-gas heat powered cycles, are well adapted to simple technology applications. They can operate without moving parts and with low-grade heat from different sources such as residual heat or

\section{${ }^{1}$ Researcher, Agric. Eng. Res. Inst., Agric. Res. Center Egypt}


solar energy. The two main technologies concerning the solid gas sorption concept are the adsorption and the chemical reaction, including metal hydrides. The similarities and differences between these systems, as well as the advantages and disadvantages of each one are extensively described by Meunier (1998). Refrigeration is an interesting application of solar energy because the incident radiation and the need for cold production both reach maximum levels in the same period. Water content of up to $25 \%$ (kg water $/ \mathrm{kg}$ zeolite) can be adsorbed and then dwsorbed by the adsorption enthalpy (Ming and Mumpton, 1993).

In developing countries, solar refrigeration is an increasingly acknowledged priority in view of the needs for food and vaccine preservation and due to the fact that solar energy is generally widely available in these countries. Different solar refrigeration systems using sorption processes have been proposed and tested with success. In relation to the solar adsorptive refrigeration systems, different types of solid-gas were considered. The zeolite-water and silica gel-water pairs were chosen for cold storage, while the activated carbon-methanol pair was chosen for ice production (Leite, 1996). Once the zeolite is fully saturated within the cooler, it must be removed for regeneration. Zeolite regeneration processes have been mostly done by thermal heating (thermal regeneration) using mechanized equipment (Pons 1996). The activated carbon-ammoniac pair was also employed for different refrigeration applications using solar energy. Zeolite, a micro pours crystalline solid is capable of adsorbing significant amounts of water vapor and other gases in their complex crystal structure.

The adsorptive systems development is still limited by the adsorber solar collector component cost, and by the intermittence of the incident solar radiation, which makes it difficult to be competitive with conventional compression systems. In the present work the description and the operation of a solar adsorptive prototype refrigerator using the zeolite water pair is studied. The system operates under an intermittent cycle, 
without heat recovering, and is aimed to regenerate the adsorber with solar energy, using a SK14 solar cooker. The adsorber is mobile and is regenerated out of the refrigerator. No condenser is applied because the solar regeneration is made in the ambient air. The purpose of the refrigerator is to cool milk in rural areas of Egypt, where no electricity is available.

\section{MATERIAL AND METHODS}

The study was conducted at Nubria research station, Agriculture research center. The experiments was stated at may 2012. Zeolite panes were used in the experiments, with dimensions of $\mathrm{P}_{1}(2,20,25), \mathrm{P}_{2}(2$, $20,18)$ and $P_{3}(2,20,11)$ in $\mathrm{cm}$ Samples mass of 350,250 and $150 \mathrm{~g}$ for the panes respectively.

\section{Material}

\subsection{Adsorbent}

Zeolite is a mineral consisting of $\mathrm{SiO}_{2}$ groups and alkali-ions. It is capable of adsorbing water vapor and other gas molecules in the cavities of its complex crystal structure. Water content up to $25 \%$ ( $\mathrm{kg}$ water $/ \mathrm{kg}$ zeolite) can be adsorbed and then it is heated up by the adsorption enthalpy. It's produced synthetically and the crystalline powder is pressed to pellets of about $0.5 \mathrm{~mm}$ diameter. Huge quantities of Zeolite are produced by chemical industries and used as molecular sieves or for washing detergents. Zeolite ingredients for used type can be shown in Table (1).

\subsection{SK14 cooker}

The SK14 is durable ralthough light, cost effective to build and easy to use. Its production capacity is approx. 600 Watts. The total aperture is $1.53 \mathrm{M}^{2}$ and with mass of $18 \mathrm{~kg}$. The focal point of heat for the SK14 is only $28 \mathrm{~cm}$ wide. This means that if the maximum amount of energy is desired, the dish must only be moved every 15-25 minutes to face the new position of the sun 
Table (1): The Zeolite characteristics.

\begin{tabular}{|l|l|}
\hline Specification & The sample \\
\hline Chemical formula per unit cell content & $\mathrm{Na}_{12}\left[\left(\mathrm{AIO}_{2}\right) 12\right] 27 \mathrm{H}_{2} \mathrm{O}$ \\
Appearance & White powder \\
Relatiye Brightness & $98 \%$ \\
Anhydrous zeolite content & $80 \%$ \\
Loss at $800^{\circ} \mathrm{c}$ & $20 \%$ \\
Calcium exchange capacity & $297 \mathrm{mgCaCO}_{3} / \mathrm{g}$ min \\
2 minutes & $210 \mathrm{mgCaCO}_{3} / \mathrm{g}$ min \\
10 minutes & $225 \mathrm{mgCaCO}_{3} / \mathrm{g}$ min \\
Heavy metals & $<0.5 \mathrm{ppm}$ \\
PH 5\% in water & 11 \\
Bulk density & $300-400 \mathrm{Kg} / \mathrm{m} 3$ \\
Particle size & Media diameter $3.5 \mathrm{micron}$ \\
& Above $10 \mathrm{micron} 1.5 \%$ \\
& Below $1 \mathrm{micron} \quad 0.2 \%$ \\
\hline
\end{tabular}

\subsection{Instruments}

Environmental conditions of temperature, relative humidity, air velocity and solar radiation were recorded at 20 minutes intervals Table (2). In the measurements of temperature, a $\mathrm{J}$ type iron-constant thermocouple was used with a manually controlled channel automatic digital thermometer with reading accuracy of $\pm 0.1{ }^{\circ} \mathrm{C}$ (Mini Thermo - Anemometer).

Table (2): The environmental of experiments.

\begin{tabular}{|l|l|}
\hline Instruments & Range \\
\hline Air Velocity: & 0.5 to $28 \mathrm{~m} / \mathrm{s}$. \\
\hline Humidity: & $10 \%$ to $95 \%$. \\
\hline Dew Point: & $0.0^{\circ} \mathrm{c}$ to $50^{\circ} \mathrm{c}$ \\
\hline Temperature: & $-18^{\circ} \mathrm{c}$ to $50^{\circ} \mathrm{c}$ \\
\hline
\end{tabular}

A radiation meter was used to monitor the variation of solar radiation over the entire drying. Moisture loss was also recorded at 20 minutes intervals during drying for determination of drying curves by a digital balance in the measurement range of $0.2 \mathrm{Kg}-10 \mathrm{Kg}$ and an accuracy of $\pm 0.02 \mathrm{~g}$.

2. Methods

\subsection{Adsorption cycle}

The prototype of solar refrigerator was constructed at Nubria research station, Agriculture research. The adsorber of refrigerator is mobile, to 
allow the regenerating process out of the system. Therefore, no condenser is used because the desorbed water is transferred to ambient air. In principle, the refrigerator may be constructed out of two vessels, the evaporator and the absorber, which are connected by a tube and a valve Figure (1-a). In the evaporator only the vapor pressure of the water is present, when the valve is opened, the water vapor in the evaporator is absorbed by the zeolite and thus the pressure is reduced. The milk starts cools down to approximately $10{ }^{\circ} \mathrm{C}$. the cooling chamber capacity is 4 liter and rest of the chamber volume allow releasing the vapor from the milk. When the adsorbent is saturated, the refrigeration process stops. Now the adsorbed vessel is heated up. The desorbed water vapor condenses in the connecting tube or in the evaporator at ambient temperature. Then by opening the valve the refrigeration process can start again. In practice the Zeolite can be regenerated during the day using solar energy Fig (1-b), at day time and at night the refrigeration process can be started. The thermal insulation and the thermal capacity of refrigeration chamber must be sufficient enough to avoid a big increase in temperature during the day.

\subsection{Experimental procedures}

At the beginning, the zeolite was saturated with water $\left(C_{h}=20 \%\right)$. The solar collector was heated up by solar simulator and after six hours the temperature of zeolite reaches $175^{\circ} \mathrm{C}$. the water vapor pressure was 50 mbar. The condenser was not cooled and the water vapor condensed at approximately $30^{\circ} \mathrm{C}$. During this process the water content decreased to $\mathrm{C}_{1}=8 \%$. At $\mathrm{t}=6 \mathrm{~h}$ the valve was closed and the sun was switched off. At $\mathrm{t}=8 \mathrm{~h}$ the collector had cooled down by opening the valve, the refrigeration process was started. Due to the adsorption enthalpy the temperature of the zeolite increased up to $70^{\circ} \mathrm{C}$, at which point, the rate of adsorption decreased and the adsorber temperature slowly tended to ambient temperature. The refrigerant was quickly cooled down to $-3^{\circ} \mathrm{C}$ (under cooled milk). Over time the cooling power decreased and due to the heat flow from the surroundings the temperature of the refrigerant slowly increased to $10^{\circ} \mathrm{C}$ after 12 hours. This experimental procedure was repeated for different desorption temperatures and different kinds of Zeolite as well as of silica gel. 


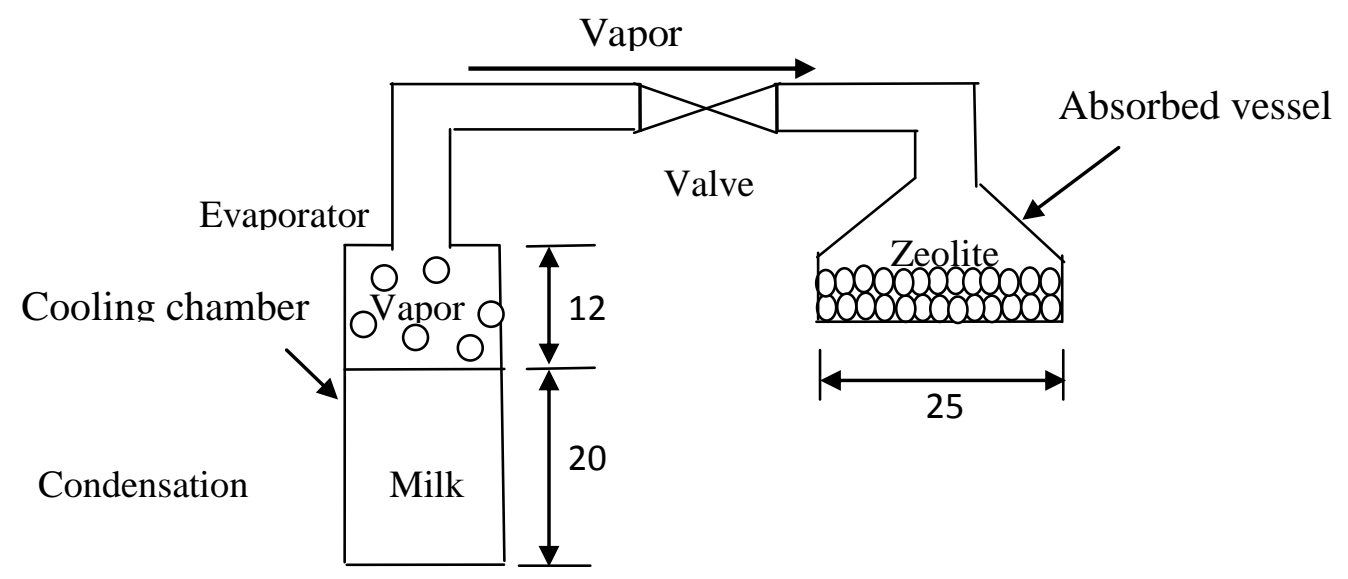

Fig. (1-a): Scheme of functioning of the Zeolite solar refrigerator for cooling milk
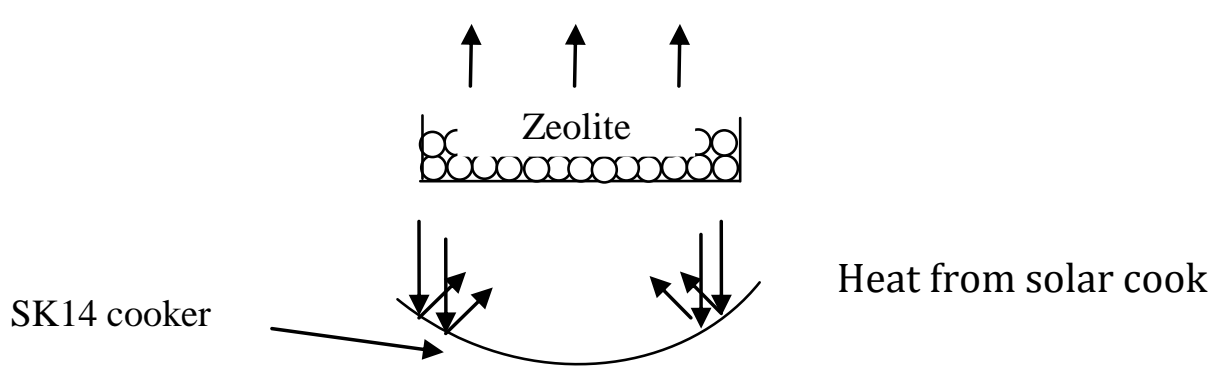

Desorptio

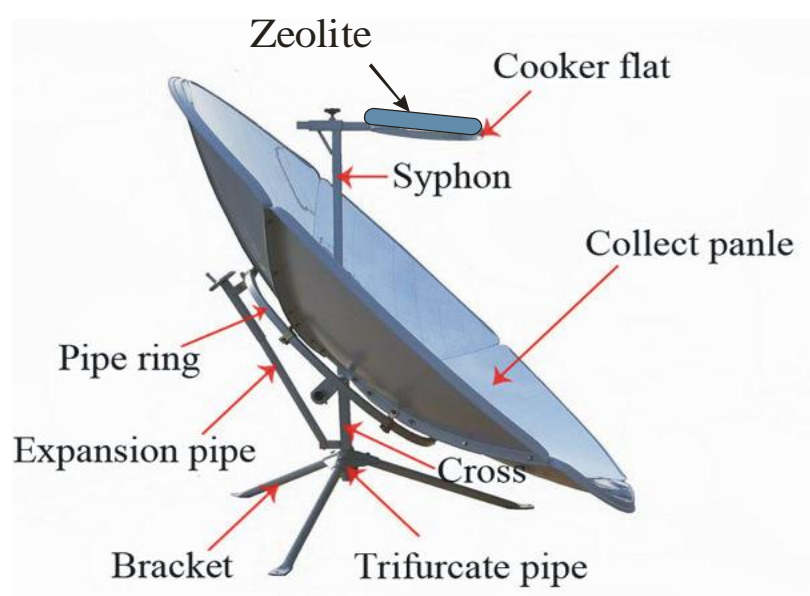

Fig. (1-b): Regeneration process of Zeolite using solar energy 
PROCESS ENGINEERING

\subsection{Measurements}

The amount of water removed from the drying material was calculated as follows:

$$
\Delta \mathrm{W}=\mathrm{W} \times \frac{\mathrm{M}_{1}-\mathrm{M}_{2}}{100-\mathrm{M}_{2}}
$$

Where:

$\mathrm{M}_{1}=$ Initial moisture content of drying material, $\% \mathrm{wb}$

$\mathrm{M}_{2}=$ Final moisture content of drying material, $\% \mathrm{wb}$

$\mathrm{W}=$ The amount of wet material to be dried, $\mathrm{kg}$

The drying kinetics relates the moisture ratio to the drying time. The moisture ratio is formulized as follows:

$$
\mathrm{MR}=\frac{\mathrm{M}-\mathrm{M}_{\mathrm{c}}}{\mathrm{M}_{0}-\mathrm{M}_{\mathrm{c}}}
$$

Where:

$\mathrm{M}=$ Moisture content of drying material at any sampling time, $\% \mathrm{db}$

$\mathrm{M}_{\mathrm{e}}=$ The equilibrium moisture content of drying material based on drying conditions.

$\mathrm{M}_{0}=$ Initial moisture content of drying material at any sampling time, $\% \mathrm{db}$

The values of the equilibrium moisture content. $\mathrm{M}_{\mathrm{e}}$ are relatively small compared to $\mathrm{M}$ and $\mathrm{M}_{0}$. Thus, moisture ratio can be calculated as follows ( Doymaz and Pala 2002)

$$
M R=\frac{M-M e}{M_{0}-M e}
$$

The weather conditions during the experiments were, solar radiation ranged from 900 to $1000 \mathrm{~W} / \mathrm{m}^{2}$, wind speeds from 2.8 to $3.9 \mathrm{~m} / \mathrm{s}$ while the ambient air temperature ranged from 2.5 to $3.5^{\circ} \mathrm{c}$.

\section{RESULTS AND DISCSINOS}

Zeolite drying curves

Figure (2) shows drying curves of the used Zeolite 80 obtained at atmospheric pressure with small three panes of $\mathrm{P}_{1}, \mathrm{P}_{2}$ and $\mathrm{P}_{3}$ samples of 
Zeolite put at solar cover for regenerating the adsorbent (Figure 1). From these curves it can be concluded that it is not recommended to reduce the humidity from its initial $(20 \%)$ dry matter at saturation to below $2 \%$. Further drying would result only in a small improvement of the capacity of the Zeolite to all sorbs water.

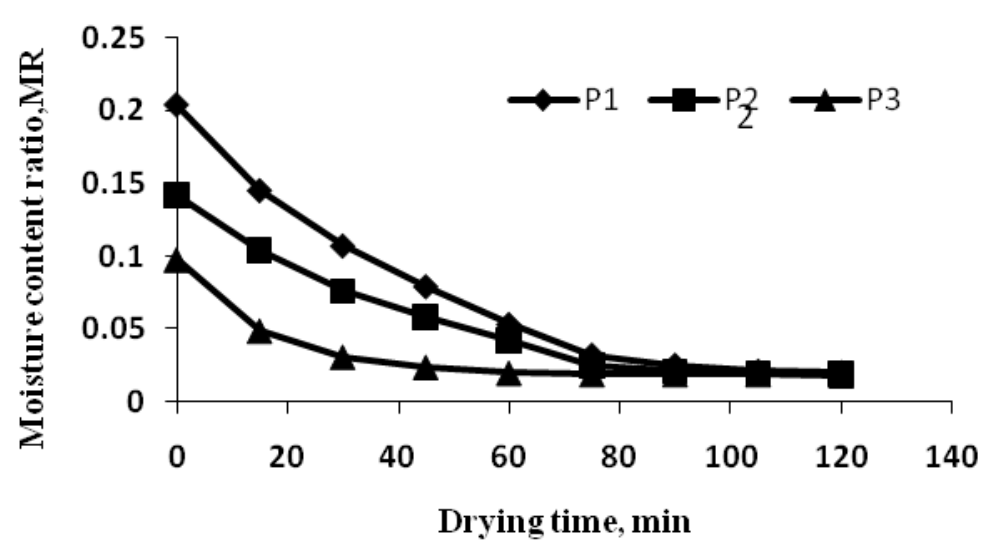

Fig. (2): Variation of moisture content with zeolite drying time.

The moisture content decrease continuously with drying time and there was no constant rate period in drying for all the sizes. The moisture ratio also varied in the same way (Fig 3).

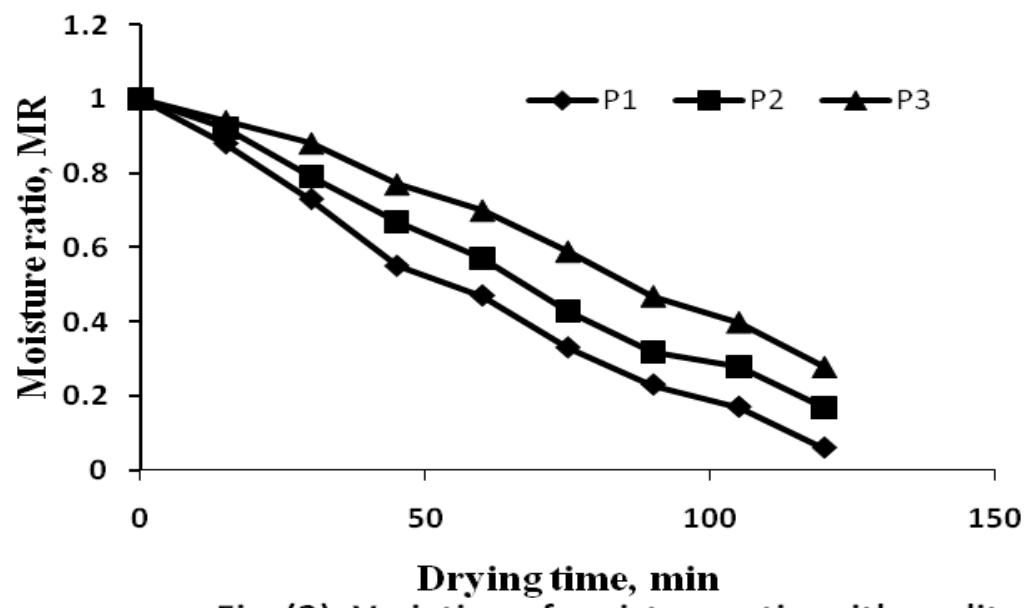

Fig. (3): Variation of moisture ratio with zeolite drying time. 
All the drying processes occurred in the falling rate period. In this period the zeolite surface was no longer saturated with water and drying rate was controlled by diffusion of moisture from the interior of the solid to the surface. The drying rate is higher at the beginning of the regeneration process and decreases continuously with increasing drying time because of at the begging of drying process the water is easy to remove from zeolite and as the end of dying zeolites catch water stronger than earlier time shown in (Fig 4).

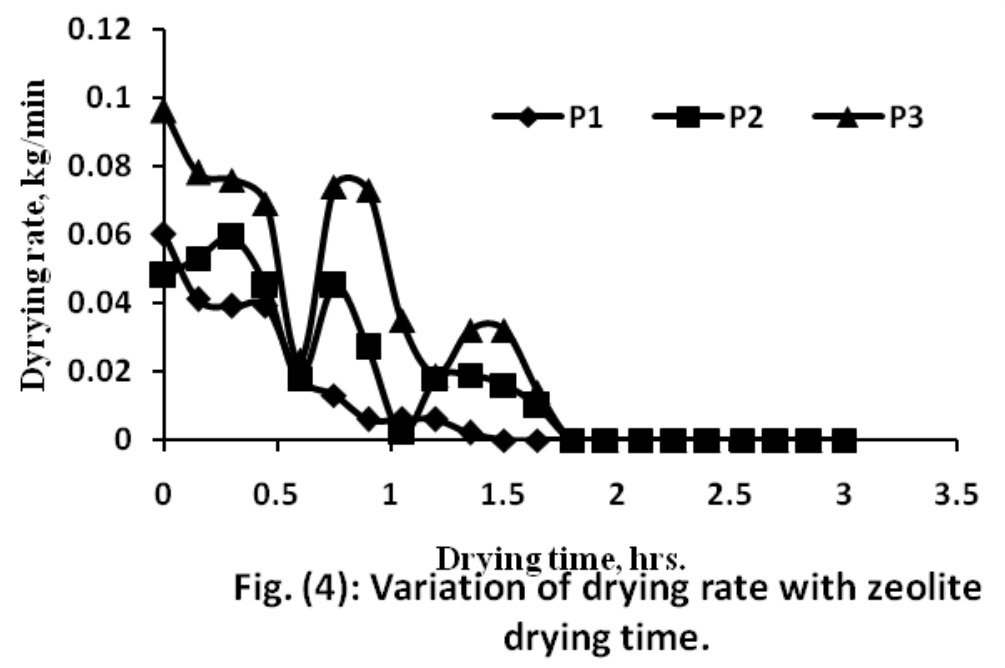

As expected size $\mathrm{P}_{1}, \mathrm{P}_{2}$ comparing with $\mathrm{P}_{3}$ had both the highest moisture content and the fastest drying rate. This is due to the small size of the sample particles of $\mathrm{P}_{3}$ that presents a large surface area for absorption and evaporation of moisture.

Mathematical modeling of drying curves

According to the results, the best mathematical model for zeolite drying curve is Doymaz (2004) with highest values of R (0.99) and lowest values of the standard error of the estimate $\left(\sigma_{\text {est }}=0.0112\right)$ best where the model is the following:

$$
\mathrm{MR}=\exp \left(-\mathrm{kt}^{\mathrm{n}}\right)
$$

Where:

MR : Dimensionless moisture ratio

$\mathrm{K}, \mathrm{n}$ : Empirical constants in drying models

The model constants for the tested panes are shown in Table (3). 
Table (3): constant value of the mathematical model for the pans

\begin{tabular}{|l|l|l|l|}
\hline $\mathrm{MR}$ & $\mathrm{P}_{1}$ & $\mathrm{P}_{2}$ & $\mathrm{P}_{3}$ \\
\hline $\mathrm{K}$ & 0.0112 & 0.11 & 0.1 \\
\hline $\mathrm{n}$ & 1.2 & 0.69 & 0.54 \\
\hline $\mathrm{R}^{2}$ & 0.9819 & 0.9855 & 0.9565 \\
\hline
\end{tabular}

Through moisture ratio modeling based on the drying time, size $\mathrm{P}_{3}$ recorded highest efficiency. The performance of the model is presented in Figure (5)

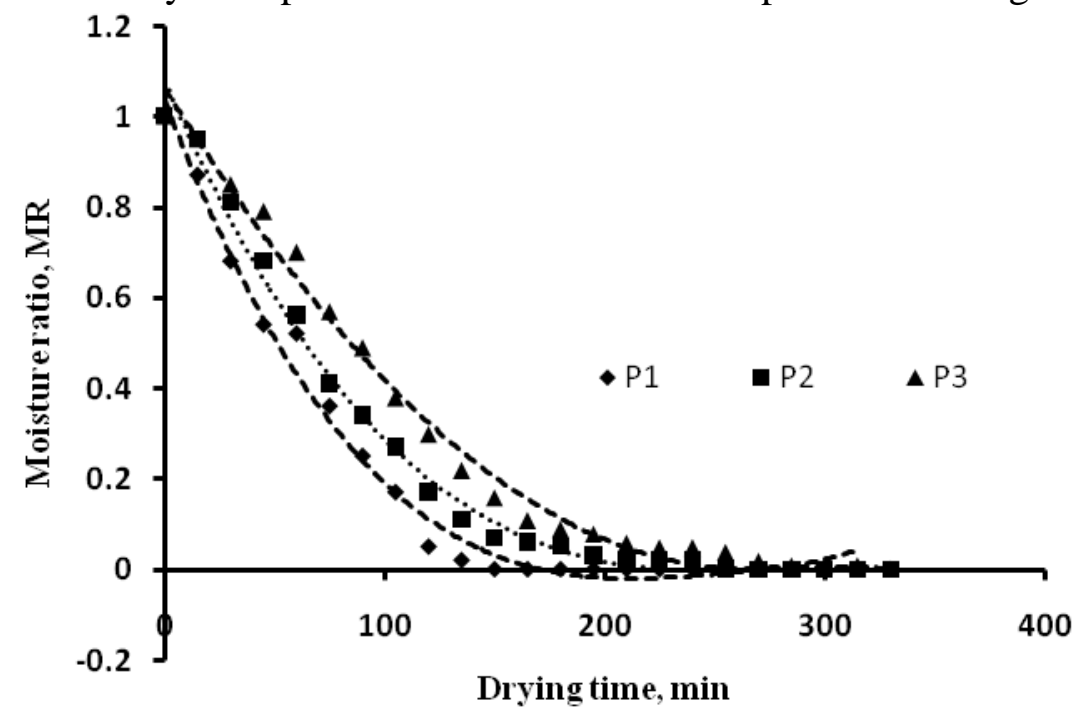

Fig. (5): Variation of experimental moisture ratio with drying time at different drying conditions.

Reducing four liters of fresh milk having temperate from $37{ }^{\circ} \mathrm{C}$ to $10{ }^{\circ} \mathrm{C}$, needs three hours using zeolite pan of $\mathrm{P}_{3}$. The zeolite pan needs to dry on solar collector 6 hours to get rid of the moisture.

Model verification

The standard error of the estimate is a measure of the accuracy of predictions. Recall that the regression line is the line that minimizes the sum of squared deviations of prediction (also called the sum of squares error). The standard error of the estimate is closely related to this quantity and is defined below: 


$$
\sigma_{e s t}=\sqrt{\frac{\sum\left(Y-Y^{\prime}\right)^{2}}{N}}
$$

Where: $\sigma_{\text {est }}$ is the standard error of the estimate, $Y$ is an actual score, $Y^{\prime}$ is a predicted score, and $\mathrm{N}$ is the number of pairs of scores. The numerator is the sum of squared differences between the actual scores and the predicted scores.

To assist further in this evaluation, another index called coefficient of efficient (Ce) was used. This coefficient was proposed by Nash and Sutcliffe (1970) and used by Masheshwari and McMahon (1993), Sharaf (2003). If $\mathrm{R}$ and Ce are close to each other, the model is free from any bias all or part of the data. $\mathrm{C}_{\mathrm{e}}$ is defined below as:

$$
C_{e}=\frac{\sum_{i=1}^{i=n}\left(X_{o i}-\bar{X}_{o}\right)^{2}-\sum_{i=1}^{i=n}\left(X_{o i}-X_{p i}\right)}{\sum_{i=1}^{i=n}\left(X_{o i}-\bar{X}_{o}\right)^{2}}
$$

Where:

$\mathrm{C}_{\mathrm{e}}=$ coefficient of efficient $\quad \mathrm{X}_{\mathrm{pi}}=$ the value of predicted measurements $\frac{\mathrm{n}}{X}=$ number of observations $X_{\mathrm{oi}}=$ the value of observed measurement $\bar{X}_{o}=$ average observed value

Figure (6) shows the relationship between predicted and measured moisture content. The A in Table (4) is the line slope and B is the line intersects with y axis. The results showed by Figure (6) and Table (4) means that the model has very high performance for describing the characteristics of drying curve. It was found that the difference between the predicted and observed values is very low.

Table (4) shows the standard error of estimate linear model $\mathrm{R}^{2}$, the standard error of the estimate $\sigma_{\text {est }}$, coefficient of efficient $C_{e}$, and correlation coefficient R of Figure (6)

Table (4): Indicates performance of model predicting

\begin{tabular}{|c|c|c|c|c|c|}
\hline$\sigma_{\text {est }}$ & $\mathrm{C}_{\mathrm{e}}$ & $\mathrm{R}^{2}$ & $\mathrm{R}$ & $\mathrm{A}$ & $\mathrm{B}$ \\
\hline 0.0112 & 0.999 & 0.999 & 0.999 & 0.999 & 0.001 \\
\hline
\end{tabular}




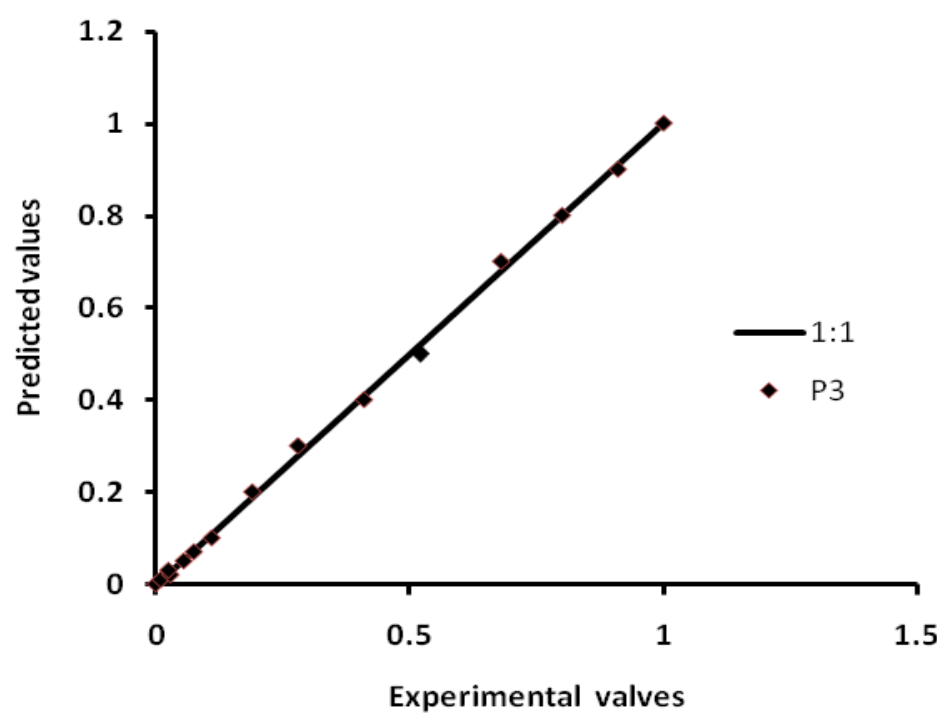

Fig. (6): Comparison of experimental and predicted moisture ratio values of zeolite $\mathrm{P3}$ for modified

Doymaz model.

Milk cooling curve

Figure (7) show the milk cooling curve during the refrigration process aginst time. From the results the milk temperature reached to $10^{\circ} \mathrm{C}$ after 180 minutes, $14^{\circ} \mathrm{C}$ after 210 minutes and $18^{\circ} \mathrm{C}$ after 240 minutes using pan $\mathrm{P}_{1}, \mathrm{P}_{2}$ and $\mathrm{P}_{3}$ respectivley. After the Zeolite sturated with the vapoure the capabilty of Zeolite to absorbe the vapor decreaced then the milk temperature begin to increase gradually. At the moment of increasing milk temerature the Zeolite should be removed and replaced with the another dried pan to keep the milk temperature at the mimumum temperature obtained.

\section{CONCLUSION}

In this study, regeneration of three Zeolite sizes of $2 \times 20 \times 25,2 \times 20 \times 18$ and $2 \times 20 \times 11 \mathrm{~cm}$ has successfully investigated. The drying occurred in the falling rate period showing Zeolite $2 \times 20 \times 25$ as the optimum size with the fastest drying rate and most efficient. According to the results of the mathematical modeling of drying of zeolite, the best describing the drying characteristic is Doymaz model. The minimum cooling temperature obtained was $10^{\circ} \mathrm{C}$ after 180 minute using pan of 
$2 \times 20 \times 25 \mathrm{~cm}$. Since zeolite size of $\mathrm{P}_{1}$ proved to be the most optimum, it is the size recommended for use in milk cooler.

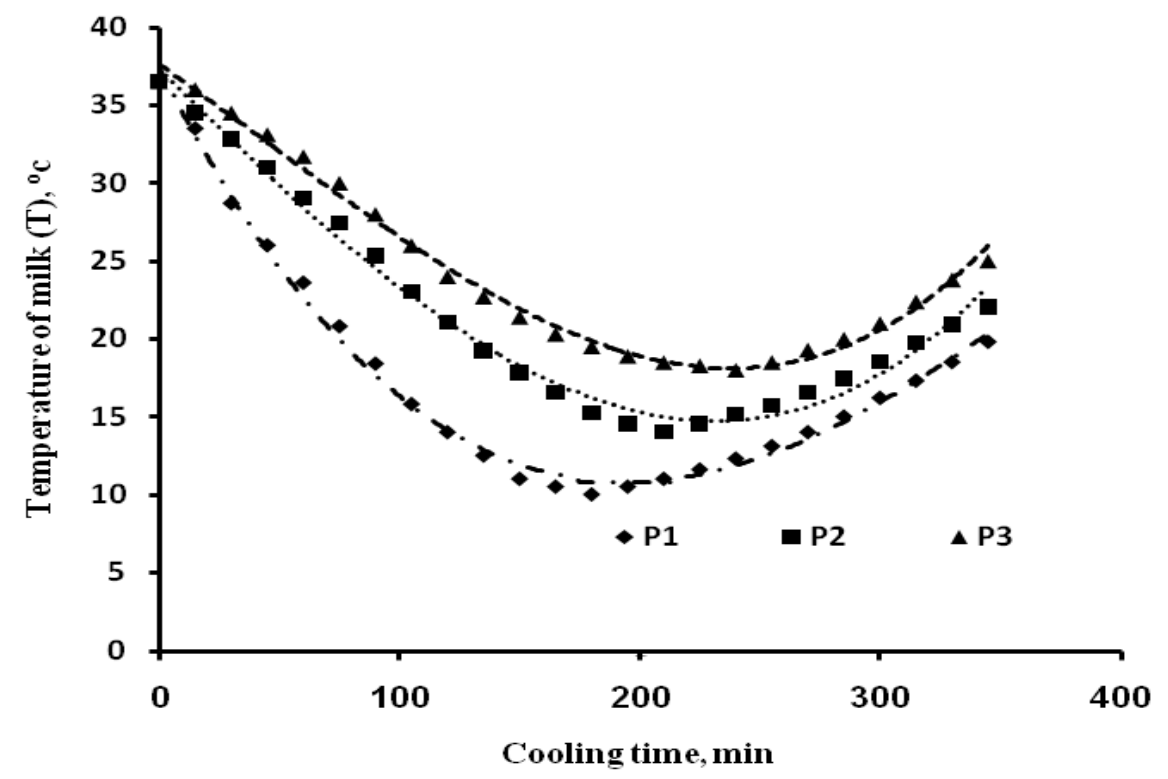

Fig. (7): Variation of milk temperature with cooling time at different milk conditions.

\section{REFERENCES}

Doymaz, I., M., Pala (2002). Hot air Drying Characteristtics of Red Pepper. Journal of food Engineering 55:335.

Doymaz, I., (2004). Drying kinetics of white mulberry. J. Food Eng., 61(3): 41-346.

Leite A. F. L. (1996) Sistema Frigorífico a Adsorcao Utilizando Carvao Ativado Metanol com Regeneracao por Energía Solar, Tese presentada en concurso publico para profesor titular, Universidade Federal da Paraíba, Campina Grande-PB, Brasil.

Meunier F. (1998). Solid sorption heat powered cycles for cooling and heat pumping application. Applied Thermal Engineering 18, pp. 715-729.

Ming D.W. and Mumpton, F.A. (1993). Zeolites in solar energy refrigeration. Transaction of American Society of Agricultural Engineers, 36:837-840

Pons, $m$ (1996). Analysis of the adsorption cycles with thermal regeneration based the entropic mean temperaturesm Applied Thermal Eng., 615-627. 


\section{PROCESS ENGINEERING}

\section{الملخص العربي \\ تطوير نظام لتبريد اللبن في المناطق الريفية \\ محيي الدين محمد مرسي'}

الهدف من الدراسة هو تبريد اللبن المنتج عند المزارع الصغير عن طريق خفض درجة حرارته

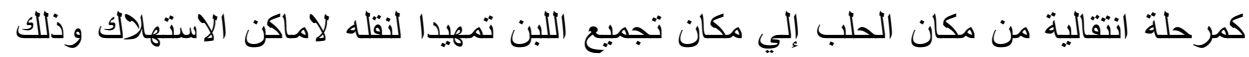

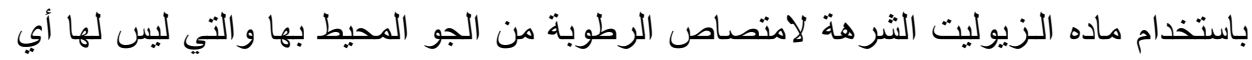

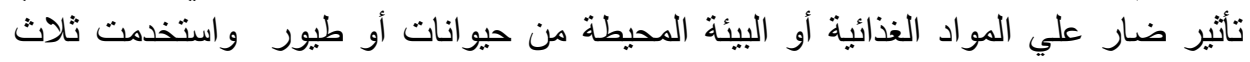

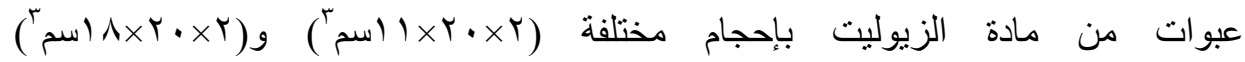

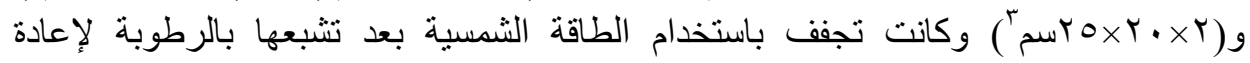

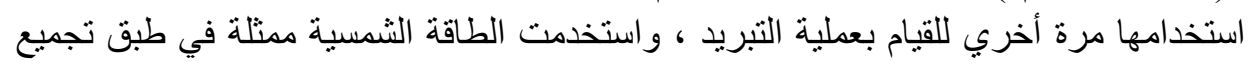

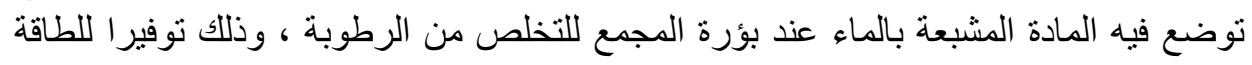

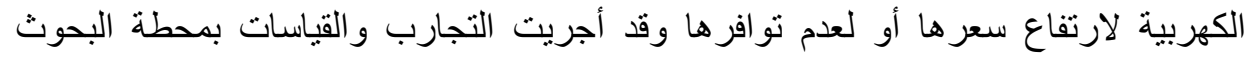

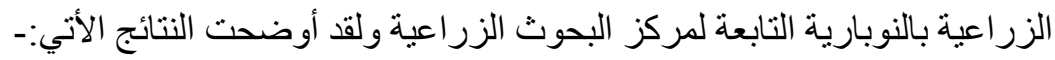

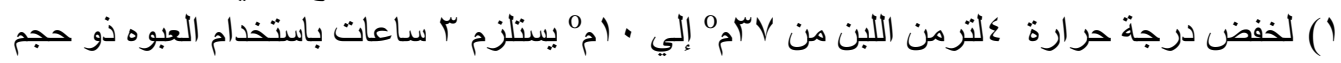

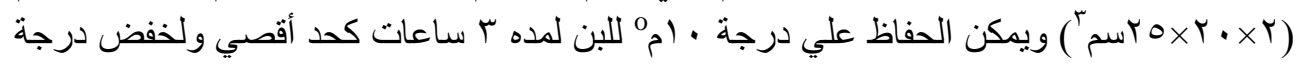

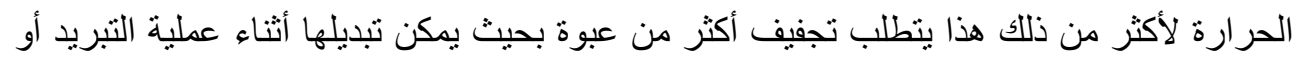

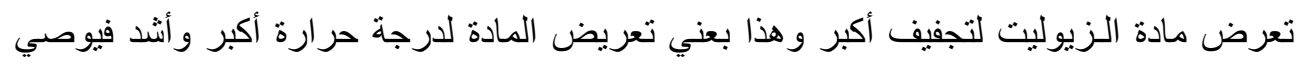

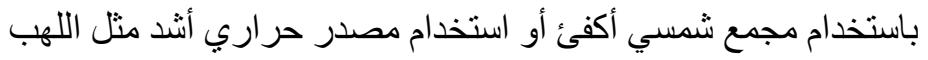

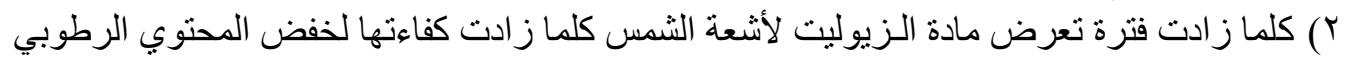

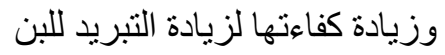

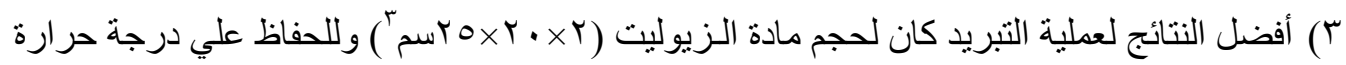

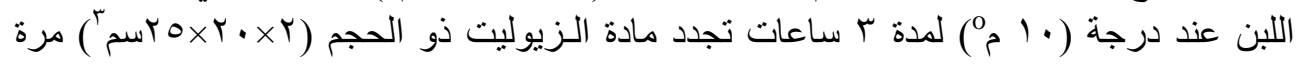

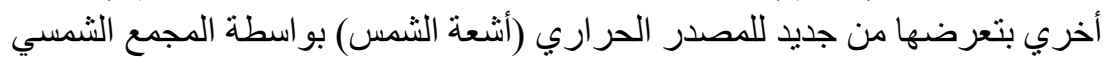
ع) أفضل نموذج لوصف عملية التجفيف لمادة الزيوليت المستخدمة في عملية التبريد هو نموذج النهي ) و الذي يعبر عنه بالمعادلة الآتية: (Doymaz) $\mathrm{MR}=\exp \left(-\mathrm{kt}^{\mathrm{n}}\right)$

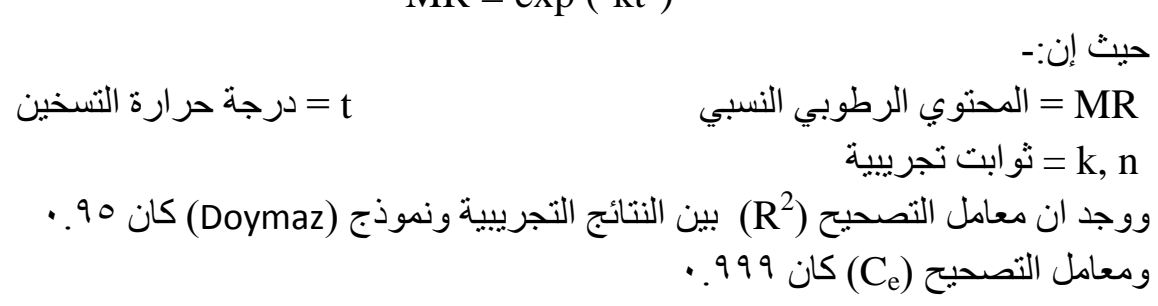

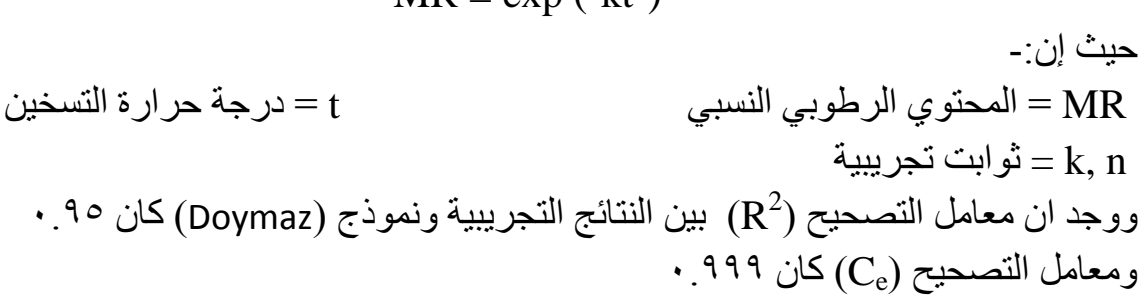
' باحث بمعهد بحوث الهزدسة الزراعية ـ مركز البحوث الزراعية - مصر. 